\title{
Kokoviljasäilörehun taloudellisuus maidontuotannossa
}

\author{
Heikki Mäkinen
}

Taloustieteen laitos, PL27, 00014 Helsingin yliopisto, heikki.makinen@helsinki.fi

\begin{abstract}
Johdanto
Maatalousyrittäjän tärkeimpänä tavoitteena pidetään yleisesti mahdollisimman hyvän taloudellisen tuloksen saavuttamista. Tavoitteeseen pääsemiseksi yrittään on kaiken aikaa etsittävä tapoja kehittää tuotantoaan ja sopeuttaa sitä muuttuviin olosuhteisiin. Viljelijä kohtaa toimintaympäristön muutokset esim. toimintaa ohjaavan institutionaalisen sääntelyn muuttumisena, kilpailutilanteen muuttumisena, hintasuhteiden muuttumisena ja teknologian sekä uusien innovaatioiden kehittymisenä. (esim. Turkki, 2000)

Ulkoapäin tuleviin muutoksiin varautumisen lisäksi yrittäjän on tarpeen tarkastella jatkuvasti myös omia toimintatapojaan ja tilan tuotantojärjestelmiä kriittisesti. Tavanomaista on, että nautakarjatilalla viljellään rehuviljaa jopa laajamittaisesti omalla kalustolla, mikä ei useinkaan ole kannattavaa toimintaa, kun otetaan huomioon viljelyn kustannukset ja viljan hinta (vrt. Ala-Mantila ja Riepponen 1998). Aaltosen ym. (1999) mukaan jo pelkät viljanviljelyn korjuu-, kuivaus- ja logistiikkakustannukset ovat kaksi kolmasosaa viljan hinnasta. Kuitenkin maitotilan tuotantojärjestelmässä viljalla on tärkeä rooli karjanlannan ja nurmien uudistamisen vuoksi. Viljan korjaaminen säilörehuksi on vanhastaan tunnettu menetelmä, jota käytetään etenkin suurehkoilla maitotiloilla (Turunen 1999), mutta sitä koskeva taloudellinen tutkimus on ollut melko vähäistä. Tässä artikkelissa esitellään tuloksia MMM:n rahoittaman kokoviljan korjuuta, säilöntää ja käyttöä koskevan tutkimushankkeen talousosiosta. Hankkeen tavoitteena oli selvittää, voidaanko kokoviljasäilörehun käytöllä parantaa maitotilan taloudellista tulosta, sekä millaisella kokoviljasäilörehun korjuuteknologialla saavutetaan paras tulos.
\end{abstract}

\section{Aineisto ja menetelmät}

Kokoviljasäilörehun sisällyttäminen maitotilan tuotannonhaarojen yhdistelmään on tuotantojärjestelmän muutos, joka vaikuttaa tilan toimintoihin laajasti. Muutoksia tapahtuu pellon käytössä, töiden ajoittumisessa, eläinten ruokinnassa ja lannan käsittelyssä. Tuotantojärjestelmien eroja voidaan suuntaa antavasti tarkastella tilamalleilla, joissa muuttuvien tekijöiden vaikutus lopputulokseen pystytään ottamaan huomioon ja muut tilan tuotantoon liittyvät tekijät pitämään vakioina. Tällaisten tilamallien käyttö maatalousekonomisessa tutkimuksessa on varsin yleistä. (esim. Turunen, 2000; Aaltonen ym., 1999)

Tässä tutkimushankkeen osassa tutkimusongelmaa tarkasteltiin maidontuottajan suunnitteluongelmana tilanteessa, jossa hänen on tehtävä pitkän aikavälin päätöksiä lehmien rehuntuotannon järjestämisestä. Tällöin rationaalisesti käyttäytyvä maidontuottaja pyrkii voiton maksimointi -oletuksesta johtuen maksimoimaan suunnittelutilanteessa kiinteiksi katsottaville tuotannontekijöille jäävää kokonaistuoton osaa tilakohtaisten rajoitusten puitteissa (Ryynänen ja Pölkki, 1978; Ryhänen ym. 1996). Tarkastelu on tilamallityyppinen, mutta mallinnus rajoittui vain niihin tekijöihin, jotka ovat erilaisia eri vaihtoehtojen välillä. Tällaisen case-tyyppisen tarkastelun tulokset eivät ole laajasti yleistettävissä, mutta antavat kuitenkin kuvan eri vaihtoehtojen paremmuudesta kyseisessä tilanteessa.

Tutkimuksessa otettiin lähtökohdaksi kaksi erikokoista olemassa olevaa maidontuotantotilaa C2tukialueelta (tilalla A 32 ha ja 20 lehmäpaikkaa, tilalla B 90 ha ja 55 lehmäpaikkaa). Näille tiloille laadittiin tutkimusongelman ratkaisun kannalta järkeviä suunnitelmia tuotannon järjestämisestä. Suunnitelmat perustuivat katetuottomenetelmään siten, että tuotannonhaarojen yhdistely tehtiin käyttäen apuna lineaarista ohjelmointia (LP). Tämän menetelmän etuna on mahdollisuus erilaisten vaihtoehtojen ja suunnittelutilanteiden monipuoliseen simulointiin sekä se, että tilalla käytettäviä välituotteita (rehut, lanta) ei tarvitse hinnoitella lainkaan. Lisäksi LP-mallin avulla voidaan tarkastella optimiratkaisun herkkyyttä esim. hintojen ja panos-tuotos -suhteiden muutokselle.

LP-menetelmän perusperiaate on, että se etsii mahdollisten tuotannonhaarojen yhdistelmien jout kosta sen, joka maksimoi tavoitefunktion arvon (Suomela ym. 1961, Doll ja Orazem, 1984). Tavoitefunktio puolestaan on eri tuotannonhaarojen yhteenlaskettu katetuotto. Erityisen tärkeää on huomata, että LP-menetelmä ei optimoi panos-tuotossuhteita. Se käyttää laskenta-aineistona annettuja tuotantofunktioiden pisteitä, jotka on ilmaistu tuotannonhaarojen katetuottolaskelmissa. Mikäli nämä on laadittu virheellisesti, myös optimoinnin tulos on harhainen. Tämä periaate pätee tietysti yleisemminkin maatilan tuotannon suunnitteluun: tulosten käyttökelpoisuus riippuu aina ennenkaikkea lähtötietojen 
oikeellisuudesta, ja laskentarutiini vain tiivistää tämän informaation tulkinnan ja päätöksenteon kannalta sopivaan muotoon.

Tiedot esimerkkitilojen resursseista ja tuotantomahdollisuuksista saatiin suoraan viljelijöiltä kyselemällä samoin kuin tarvittavien katetuottolaskelmien laatimisessa käytettävät tiedot. Myös tuotteiden ja panosten hintoina käytettiin esimerkkitilojen saamia ja maksamia hintoja. Säilörehun korjuuketjut ja korjuun työnmenekit perustuvat kuitenkin tämän tutkimushankkeen teknologiaosioon, ja kokoviljasäilörehun rehuarvot hankkeen kotieläinosioon. Eläinten ruokinta suunniteltiin toteutettavaksi ruokintanormien mukaan, tällöin maidontuotannon oletetaan pysyvän normiruokinnalla vakiona, vaikka karkearehujen käyttösuhteet muuttuvat.

Vertailukohdaksi laadittiin tilojen nykyistä tuotantoa mahdollisimman hyvin kuvaava malli. Näissä perusmalleissa karkearehuna käytettiin pelkästään esikuivattua nurmisäilörehua, joka korjattiin tarkkuussilppurilla, sekä tilalla A lisäksi laidunta. Vaihtoehtoisissa malleissa tarkasteltiin tilannetta, joka oli muuten samanlainen kuin perusmallissa, mutta jossa puolet lehmien karkearehusta ja kaikki nuoren karjan karkearehu oli kokoviljasäilörehua, ja kokoviljasäilörehun viljelyala määräytyi tämän tarpeen mukaan. Molempien tilojen säilörehunkorjuun ajateltiin tapahtuvan yhteistyönä toisen tilan kanssa, mikä vastaa myös todellisuutta näillä tiloilla ja on järkevää sekä työnkäytön että konekustannusten kannalta. Säilörehun korjuuketjuina vertailtiin seuraavia vaihtoehtoja:

1. Niittomurskain + tarkkuussilppuri + perävaunut $(2 \mathrm{kpl})+$ etukuormain, vuotuiskustannus yhteensä $5381 € /$ tila

2. Niittomurskain + pyöröpaalain + käärintälaite + etukuormain ja paalinostin, vuotuiskustannus yhteensä $3803 € /$ tila

3. Niittomurskain + silppuava noukinvaunu + etukuormain, vuotuiskustannus yhteensä 4190 $€ /$ tila

4. Pyöröpaalausurakointi: urakoitsijan taksan mukaan + etukuormain ja paalinostin, joista vuotuiskustannus yhteensä $466 € /$ vuosi

5. Tarkkuussilppuri- ja noukinvaunuketjuissa lisäksi kattamattomat rehusiilot, joiden vuotuinen kustannus tilalla A $997 €$ ja tilalla B $5759 €$

Kussakin laskelmassa eri tuotantoprosessit (esim. lehmä, hieho, säilörehu, rehuviljat, peltoalatuet) yhdisteltiin LP-matriisilla. Matriisiin asetettiin rajoitteita, jotka määräsivät $\mathrm{mm}$. suurimman mahdollisen peltoalan ja lehmämäärän, sekä työnmenekin etenkin työhuippujen aikana. Lisäksi rajoite- ja taseyhtälöillä sidottiin yhteen mm. karjanlannan tuotettu määrä ja käyttömahdollisuus sekä nurmien uudistamistarve ja viljojen viljelyalat. Kaikissa malleissa tilan omaa työpanosta oli mahdollista täydentää ostamalla lisätyövoimaa.

Matriisien ratkaisuina saatiin tilan kokonaiskatetuoton maksimoiva tuotannonhaarojen yhdistelmä. Tästä varsinaisesta katetuotosta vähennettiin vielä kyseiseen vaihtoehtoon liittyvän rehunkorjuukoneketjun aiheuttama vuotuinen kustannus, joka sisältää koneiden poiston, koron ja kunnossapitokustannuksen. Niissä vaihtoehdoissa, joissa säilörehut korjataan ja varastoidaan irtotavarana (tarkkuussilppuri- ja noukinvaunuketjut), kokonaiskatteesta vähennettiin myös tuorerehuvaraston vuotuinen kustannus. Näin saatua tilakohtaista katetuottoa kutsutaan tässä yhteydessä suunnittelukatteeksi. Korjuukoneiden ja rehuvarastojen vuotuinen kustannus on katsottava muuttuvaksi kustannukseksi, sillä pitkän aikavälin suunnittelutilanteessa ollaan tekemässä päätöstä rehunkorjuuteknologian valinnasta, ja siitä aiheutuvilla kustannuksilla on keskeinen merkitys päätöksenteossa.

Jotta tilan tuotanto kokonaisuutena tarkastellen olisi kannattavaa, olisi suunnittelukatteella kyettävä peittämään kaikki ne kustannukset, joita ei laskentamallissa ole vielä huomioitu. Tällaisia ovat mm. pellon, salaojien, kotieläinrakennuksen, maitokiintiön, traktoreiden ja muun peltoviljelykaluston vuotuinen kustannus, tuotannonhaaroihin sisältymätön työkustannus sekä yleiskustannukset. Näitä ei kuitenkaan tässä tutkimuksessa määritetty, sillä suunnittelukate on tutkimuksen tavoitteiden kannalta vaihtoehtojen keskinäistä paremmuutta riittävän hyvin kuvaava tunnusluku.

\section{Tulokset ja tulosten tarkastelu}

Kaikissa laskentamalleissa optimiratkaisu perustui täysimääräiseen maidontuotantoon, eli lehmiä kannatti pitää niin paljon kuin navetan koko ja maitokiintiö sallivat. Pellon käyttö oli lähes täysin sidoksissa eläinten tarvitsemaan rehualaan; tästä mahdollisesti yli jäävä peltoala kohdentui rehuviljalle, sillä se oli malleissa ainoa tapa, jolla ylimääräistä peltoa voitiin hyödyntää. Peltoalan runsauden ansi osta nurmien uudistaminen ja karjanlannan sijoittaminen nurmirikkoon eivät tuottaneet ongelmia.

Kun lehmien tuotostason oletettiin pysyvän vakiona, kaikki kokoviljasäilörehua sisältävät vaihtoehdot tuottivat molemmilla esimerkkitiloilla korkeamman suunnittelukatteen (tilalla A 30742 - 
$32537 €$, tilalla B 116152 - $124126 €$ ) kuin pelkkään nurmisäilörehuun perustuva vaihtoehto (vastaavasti 30672 ja $115924 €$ ). Parhaan tuloksen antoivat tilalla A molemmat pyöröpaalausvaihtoehdot, joilla suunnittelukate oli noin $1860 €$ eli $6 \%$ parempi kuin perusvaihtoehdossa. Myös tilalla B pyöröpaalaus oli paras vaihtoehto, siinä suunnittelukate oli $8202 €(7,1 \%)$ perusvaihtoehtoa parempi. Tilalla B kaikki oman kaluston käyttöön perustuvat vaihtoehdot olivat paalausurakointia edullisempia, sillä korjattavan pinta-alan kasvaessa koneketjun kustannus jakautuu yhä suuremmalle pinta-alalle, kun taas urakoitsijan veloitus kasvaa suoraviivaisesti pinta-alan myötä. Peltoalatukien osuus suunnittelukatteesta oli huomattavan suuri, tilalla A $52-54 \%$ ja tilalla B $36-41 \%$. Ratkaisujen rakenne (kantaratkaisu) ei ollut herkkä minkään tuotanto-, osto- tai myyntiprosessin katetuoton tai hinnan suhteen. Tämä johtuu siitä, että näillä tiloilla, tässä suunnittelutilanteessa ja käytetyillä panostuotossuhteilla maidontuotannosta saatava katetuotto on ylivoimaisen suuri viljanviljelyn katetuottoon verrattuna.

Ratkaisujen antama euromääräinen suunnittelukate sen sijaan muuttui heti, kun tuotosmääriä muutettiin Kokoviljasäilörehua sisältävien mallien suunnittelukate aleni merkittävästi, kun lehmien maitotuotosta pienennettiin. Viiden prosentin lasku tuotostasossa johti tilan A suunnittelukatteen alenemiseeen 3640 eurolla kussakin vaihtoehdossa (n. $11 \%$ ), jolloin niiden suunnittelukate jäi alhaisemmaksi kuin perusmallissa. Tilalla B vastaava maitotuotoksen lasku alensi kokoviljasäilörehua sisältävien mallien suunnittelukatetta $10239 €($ n. 8 - $9 \%$ ), jolloin kaikkien vaihtoehtojen kannattavuus jäi heikommaksi kuin perusmallissa. Tuotostaso on keskeinen kannattavuuteen vaikuttava tekijä, mutta Jaakkolan ym. (2002) mukaan näyttää kuitenkin siltä, että mikäli viljasäilörehu on riittävän hyvälaatuista, tuotostason laskun riski on pieni.

Tiloilla oli käytettävissään suhteellisen paljon peltoa lypsylehmää kohti (1,6 ha/lehmäpaikka). Kun tilojen peltoalaa laskentamalleissa supistettiin 1,4 hehtaariin/lehmäpaikka, kokoviljasäilörehuvaihtoehtojen suhteellinen kannattavuus parani. Tilalla A kokoviljasäilörehua käytettäessä saatiin nyt $10-18 \%$ ja tilalla B $14-19 \%$ suurempi suunnittelukate kuin pelkkään nurmisäilörehuun perustur vassa mallissa. Viime mainitussa lannan sijoittaminen kynnökselle vaati rehuviljojen suhteellisen viljelyalan säilyttämistä riittävän suurena (väh. $1 / 3$ nurmialasta), jolloin taas nurmien viljelyala ja tämän seurauksena suurin mahdollinen lehmien määrä laski. Kokoviljasäilörehua tuotettaessa tätä ongelmaa ei ollut, koska lanta voidaan ongelmitta sijoittaa säilörehuksi korjattavaa vilja-alaa perustettaessa.

Malleilla simuloitiin myös tilannetta, jossa peltoala pysyi ennallaan, mutta lehmien maksimimäärän sallittiin nousta neljänneksen alkuperäistä maksimia suuremmaksi. Nurmisäilörehumallissa lehmämäärän kasvattaminen ei onnistunut kummallakaan tilalla, sillä rajoitteiksi tulivat sekä lannan käyttö että nurmien uudistaminen. Kokoviljasäilörehumalleissa lehmämäärä kasvoi uuteen maksimiin, eikä sen enempää lanta kuin nurmien uudistaminenkaan aiheuttanut ongelmia. Tilan ulkopuolisen työvoiman tarve luonnollisesti kasvoi, mikä toi edelleen esiin kokoviljasäilörehua sisältävien vaihtoehtojen suhteellisen edullisuuden, kun karkearehun korjuun ajoittuminen kahden työhuipun sijasta kolmeen tehosti tilan oman työvoiman käyttöä.

\section{Johtopäätökset}

Tämän tutkimuksen tulosten mukaan maitotilan taloudellista tulosta voidaan jossain määrin parantaa liittämällä hyvälaatuinen kokoviljasäilörehu osaksi tilan tuotantojärjestelmää. Myös Turusen (2000) tutkimuksessa kokoviljasäilörehun avulla oli mahdollista parantaa maidontuotannon kannattavuutta. Saavutettava hyöty riippuu ennenkaikkea kokoviljasäilörehun laadusta ruokinnassa sekä kunkin tilan olosuhteista ja sillä jo olevista resursseista ja tuotantovälineistä. Resurssitekijöistä tärkein on tilan peltoalan ja eläinmäärän, ja sen myötä karjanlannan määrän välinen suhde. Matala eläinyksikkö/peltoala -suhde ei aiheuta niin suuria ongelmia kuin korkea eläinyksikkö/peltoala -suhde. Jälkimmäisessä tapauksessa tilan pellonkäyttöön liittyviä rajoitteita lannan ja nurmien uudistamisen osalta voidaan väljentää kokoviljasäilörehun avulla. Tällöin tilan maidontuotannon laajentaminen on pellonkäytön osalta helpompaa, kuin pelkkää nurmisäilörehua tuotettaessa. Lannankäytön ongelmia voidaan tietenkin ainakin jossain määrin ratkaista käyttämällä sellaista lannanlevitysteknologiaa, jolla lanta voidaan sijoittaa nurmeen. Tästä aiheutuu kuitenkin lisäkustannuksia sekä puhtausriskejä, jotka on otettava huomioon päätöstä tehtäessä (Sipilä ja Pehkonen 1998, s. 150). Mikäli navetassa on kuivalantamenetelmä, ei lannan levittäminen kasvavaan nurmeen tule lainkaan kysymykseen.

Kokoviljasäilörehua käytettäessä lisähyötyä tuottaa myös säilörehunkorjuun työhuippujen tasoittuminen sekä kokoviljasäilörehun satoisuudesta johtuva viljelyn parempi suhteellinen kannattavuus nurmisäilörehuun ja rehuviljaan verrattuna. Kokoviljasäilörehua käytettäessä tilan oman rehuviljan 
tuotannon sijasta voidaan käyttää entistä enemmän ostettua viljaa, joka on nykyisten hintasuhteiden vallitessa selvästi edullisin lehmien rehu

Tarkasteluaikavälin pidetessä yhä suurempi osa maitotilan kustannuksista on muuttuvia. Myös rehunkorjuukaluston ja rehuvaraston vuotuinen kustannus on pitkällä aikavälillä muuttuva, joten tuotannon pitkän aikavälin kannattavuuden kannalta kaluston valinnalla on keskeinen merkitys. Tässä tutkimuksessa havaittiin, että pienemmällä (20 lehmää) tilalla pyöröpaalaus joko urakointina tai omalla kalustolla on edullisin rehunkorjuutapa. Suuremmalla tilalla (55 lehmää) oma pyöröpaalain- tai noukinvaunu muodostavat edullisimman korjuuketjun. Eri korjuuketjujen väliset erot tilojen suunnittelukatteessa olivat melko pieniä, eli jos ketjujen hankintahinnat poikkeavat olennaisesti siitä, mitä tämän tutkimuksen konekustannuslaskelmissa arvioitiin, ketjujen keskinäinen edullisuus saattaa muuttua. Koneketjujen keskinäisestä edullisuudesta tehdyt päätelmät ovat samansuuntaisia Seppälän ym. (2002) nurmirehun korjuun taloudellisuutta koskeneen tutkimuksen kanssa.

Säilörehun korjuu urakointina on edullisuutensa vuoksi harkinnan arvoinen vaihtoehto etenkin pienille maitotiloille. Tiloilla, joilla tilojen välisen koneyhteistyön järjestäminen ei onnistu, se on yli voimainen edullisuudeltaan. Lisäksi se saattaa olla erinomainen siirtymäkauden strategia, jolla kustannuksia aiheuttavaa investointipäätöstä voidaan lisäinformaation toivossa lykätä myöhempään ajankohtaan.

Kokoviljasäilörehun hyvyys tai huonous tilan talouden kannalta kulminoituu kysymykseen rehun ruokinnallisesta laadusta sekä ruokinnan järjestämisestä. Jotta viljasäilörehu olisi kilpailukykyistä nurmirehuun verrattuna, sen on oltava tuotantovaikutukseltaan vähintäänkin lähellä nurmisäilörehua. Lopuksi on vielä syytä korostaa, että tässä esitetyt tulokset perustuvat todellisuutta kuvaaviin yksinkertaistettuihin malleihin. Tämän vuoksi tuloksia tulee tarkastella vain suuntaa antavina, eikä niiden perusteella voi tehdä pitkälle meneviä johtopäätöksiä. Tilakohtaiset ratkaisut ja investointipäätökset tulee aina perustaa tarkkaan tapauskohtaiseen tiedonhankintaan ja suunnitteluun.

Kokoviljasäilörehun käyttö tarjoaa nautakarjatiloille ennen kaikkea joustavuutta tuotannon järjestämiseen. Saavutettava joustavuus on selkeästi suurin kokoviljasäilörehun käytöstä saatava hyöty. Joustavuus ja mahdollisuus sopeuttaa tuotantoa suhteellisen nopeasti olosuhteiden mukaan ilmenevät niin pellon käytössä, karjanlannan sijoittamisessa kuin korjuutöiden tekemisessäkin. Nämä joustavuuselementit ovat saavutettavissa ilman, että niistä aiheutuu lisäkustannuksia tai että tilan taloudellisesta tuloksesta joudutaan tinkimään.

\section{Lähteet:}

Aaltonen, J., Järvenpää, M., Klemola, E. \& Laurila, I. P. 1999. Viljan korjuu-, kuivaus- ja logistiikkakustannukset Suomessa. Maatalouden tal. tutk.lait. selvityksiä 2: 1-22.

Ala-Mantila, O. \& Riepponen, L. 1998. Maatalouden tuotantokustannukset Suomessa. Maatalouden tal. tutk.lait. julk. 222: 1-120.

Doll, J. P., \& Orazem, F. 1984. Production Economics. Theory with Applications. 2nd. ed. 470 p.

Jaakkola, S., Heikkilä, T., Saarisalo, E. \& Huhtanen, P. 2002. Kokoviljasäilörehun soveltuvuus lehmien ruokintaan. Teoksessa: Saarisalo, E. \& Topi-Hulmi, M. (toim.). Rehuvaihtoehtoja nautakarjatiloille. Seminaari Jokioisissa 29.4.2002. Suomen Nurmiyhdistys, julkaisu nro 18: 31-43.

Järveläinen, V-P, Ollonqvist, P., Ryhänen, M. ja Ylätalo, M. 1997. Metsä maatilataloudessa yhteissuunnittelun ongelmia ja hasteita. Metsätieteen aikakauskirja Folia Forestalia 4: 525-536.

Seppälä, R., Ryhänen, M., Sipiläinen, T., Rinne, M., Huhtanen, P. \& Suokannas, A. 2002. Säilörehu maatilan taloudessa - pitkän aikavälin näkökulma. Teoksessa: Ryhänen, M. \& Sipiläinen, T. (toim.) Nurmisäilörehu maatilan taloudessa. Helsingin yliopisto, Taloustieteen laitos, julkaisu nro 35: 5-54.

Ryhänen, M., Ryynänen, V. \& Seppälä, E. 1996. Maatilan tuotannon suunnittelu ja kehittäminen. Helsingin yliopisto, Taloustieteen laitos, oppikirjoja nro 2: 1-81.

Sipilä, I. \& Pehkonen, A. (toim.) 1998. Karjanlannan ympäristöystävällinen ja kustannustehokas käyttö, MMM:n karjanlantatutkimusohjelman 1995 - 1997 loppuraportti. Maatalouden tal. tutk.lait. julk. 87: 1-156.

Turkki. A. 2000. Liikkenjohtamisen merkitys maitotiloilla. Teoksessa Maataloustieteen päivät 2000, Talous ja teknologia. Maatalouden tal. tutk.lait. julk. 94: 161-171.

Turunen, H. 1999. Kokoviljasäilörehu osana nurmituotantoon liittyviä suunnitelmia. Maatalouden tal. tutk.lait. selvityksiä 12/1999: 24-35.

Turunen, H. 2000. Kokoviljasäilörehun viljelyn tuotantokustannukset ja kannattavuus maidontuotannossa. Maatalouden tal. tutk.lait. selvityksiä 6/2000: 1-55. 